\title{
Obstetric and Neonatal Outcomes of Delayed Interval Delivery in a Twin Pregnancy: A Case Report
}

\author{
İkiz Gebelikte Gecikmiş Aralıkla Doğum Eyleminin Obstetrik ve Neonatal Sonuçları: Olgu Sunumu
}

\author{
Şule Yildiz Oguz ${ }^{1}$,Esra Bilir ${ }^{2}$, Merve Ozturk³ ${ }^{3}$ Onur Karabacak ${ }^{4}$ \\ ${ }^{1}$ Department of Obstetrics and Gynecology, Koc University Hospital, Istanbul, Turkey \\ ${ }^{2}$ Koc University, School of Medicine, Istanbul, Turkey \\ ${ }^{3}$ Dr.Zekai Tahir Burak Women's Health Education and Research Hospital, Department of Obstetrics and Gynecology, Division of Perinatology, Ankara, Turkey \\ ${ }^{4}$ Department of Obstetrics and Gynecology, Gazi University Faculty of Medicine, Ankara, Turkey
}

\section{ABSTRACT}

Patients with multiple pregnancies are at greater risk of preterm labor and delivery which is associated with increased risk of perinatal morbidity and mortality. We report a case of delayed-interval delivery of a twin pregnancy with the survival of the second fetus. The patient was hospitalized at 24 weeks and 3 days gestational age (GA) due to premature rupture of the membrane of the first amniotic sac. At 26 weeks of $\mathrm{GA}$, the first fetus was born vaginally and died due to prematurity. To keep the second fetus in utero and minimize the complications, emergency McDonald cerclage was performed, and tocolysis, magnesium sulfate, betamethasone, and antibiotics were administrated. Despite our treatment at 28 weeks and 2 days gestational age, the second fetus was born via cesarean section due to breech presentation. At 10 months of corrected age, she exhibited normal development. She is now 6 years old and does not have sequel.

Key Words: Multiple pregnancy; preterm labor; cervical cerclage; magnesium sulfate; delayed interval delivery

Received: 09.06 .2018
Accepted: 03.11.2019

\section{ÖZET}

Çoğul gebeliği olan hastalar preterm doğum açısından artmış risk altındadır ve bu da artmış perinatal morbidite ve mortalite riskini beraberinde getirir. Bu vakada ikiz gebelikte birinci bebeğin erken doğumu sonrasında kaybedilmesi ve ikinci bebeğin gecikmiş aralıkla doğumu ile ilgili bir olgu sunulmuştur. Hasta birinci fetüsün amniotik kese membranının erken rüptürü nedeniyle 24 hafta 3 günlük gebe iken hastaneye yatırılmışır. Gebeliğin 26. haftasında, ilk fetus vajinal yolla makat doğmuş ve prematürite komplikasyonları nedeniyle kaybedilmiştir. ìkinci fetüsün intrauterin tutulması ve komplikasyonlarının en aza indirilmesi için acil McDonald serklaj yapılmış ve tokoliz, magnezyum sülfat, betametazon ve antibiyotikler uygulanmıştır. Hasta 28 hafta 2 günlük gebe iken tedaviye rağmen suyu gelmesi üzerine makat geliş nedeniyle sezaryen ile doğurtulmuştur. Düzeltilmiş yaştan sonraki 10. ayda normal gelişim gösteren bebek şu anda 6 yaşında olup sağlıkıdır.

Anahtar Szcükler: çoğul gebelik, erken doğum, servikal serklaj, magnezyum sülfat, gecikmiş aralıkla doğum

Geliş Tarihi: 06.09.2018

Kabul Tarihi: 11.03.2019

\section{INTRODUCTION}

Delayed interval delivery (DID) is first described by Carson in 1880, which is an option to improve the remaining fetus(es) prognosis when the delivery of the first fetus is inevitable in a multiple pregnancy. (1). Cervical cerclage, tocolysis, bed rest, antibiotic therapy, are the options to delay the birth of the remaining fetuses after the first fetus delivered (1). However, the optimal management is controversial. Herein, we report a case of a dichorionic diamniotic twin pregnancy that was successfully managed with DID.

\section{CASE REPORT}

In 2012, a 30-year-old primigravid woman at 24 weeks 3 days gestational age (GA) presented with vaginal gush of fluid to The Emergency Department, Gazi University Hospital. She had a dichorionic diamniotic twin pregnancy conceived with in vitro fertilization treatment. Her past medical history was unremarkable. Sterile speculum examination confirmed amniotic membrane rupture. Uterine contraction was not detected on cardiotocography.

Address for Correspondence / Yazışma Adresi: Sule Yildiz Oguz, MD, Koç University Hospital, Maltepe Mahallesi, Topkapı Cd. No:4, 34010 Zeytinburnu/İstanbul, Turkey E-mail: yildizsuledr@gmail.com

CTelif Hakkı 2019 Gazi Üniversitesi Tıp Fakültesi - Makale metnine http://medicaljournal.gazi.edu.tr/ web adresinden ulaşılabilir.

CCopyright 2019 by Gazi University Medical Faculty - Available on-line at web site http://medicaljournal.gazi.edu.tr/

doi:http://dx.doi.org/10.12996/gmj.2019.48 
Transabdominal ultrasound examination showed that the first fetus, 736gram estimated fetal weight consistent with the GA, was in transverse position with severe oligohydramnios. The second fetus, 734-gram estimated fetal weight consistent with the GA, was in vertex position, with a normal amount of amniotic fluid. Both fetal heart rates (FHR) were reassuring. She was hospitalized with the diagnosis of preterm premature rupture of membranes (PPROM).

In order to accelerate fetal lung maturation, betamethasone ( 2 doses of 12 mg every 12 hours intramuscularly) was given. Intraamniotic infection was ruled out at admission with the absence of maternal fever, leukocytosis, and uterine tenderness, and normal serum $C$ reactive protein (CRP) level. Ampicillin-sulbactam ( $1 \mathrm{~g}$ every 6 hours intravenously) was started and continued for seven days. Nifedipine ( $20 \mathrm{mg}$ every 6 hours orally) was given until the delivery of the second fetus. Due to the high possibility of labor, magnesium sulfate was given intravenously with a loading dose of $4 \mathrm{~g} / \mathrm{h}$ and continued at the maintenance dose of $1 \mathrm{~g} / \mathrm{h}$ for two days for fetal neuroprotection. The patient was followed by a daily assessment of vitals, uterine tenderness, foul-smelling discharge, CRP, d-dimer, erythrocyte sedimentation rate, and white blood cell count which were remained within normal range. FHRs were monitored every 6 hours.

On the 10th day of hospitalization, the vaginal examination after she complained about a pressure revealed full cervical dilatation. Uterine contraction was not detected on cardiotocography which supported cervical insufficiency. The first fetus' station was $>+1$ with frank breech position; hence, she was delivered vaginally and weighed 800 grams. One-minute and five-minute APGAR scores were 0 and 1 , respectively. The cord was highly ligated, and the placenta was left in utero. Since the contractions were ceased with intact amniotic membrane, a normal amount of amniotic fluid, reassuring FHR, a McDonald cerclage procedure with polyester fiber suture was placed under general anesthesia. Two more doses of weekly $6 \mathrm{mg}$ betamethasone injections were administered until the delivery of the second fetus. Hydroxyprogesterone (a single dose $250 \mathrm{mg}$ intramuscularly) was administered. Indomethacin (100 $\mathrm{mg}$ rectally) was given as tocolytics. Magnesium sulfate infusion was restarted at the same dosage as above and continued for 24 hours for fetal neuroprotection. Antibiotic prophylaxis with ceftriaxone (1g every 12 hours intravenously), and clindamycin ( $900 \mathrm{mg}$ every 8 hours intravenously) were initiated, and on the fifth day, they were changed to oral amoxicillin-clavulanate (1 g every 12 hours) and ornidazole (500 mg every 12 hours).

Maternal monitoring was continued as defined above without infection sign. FHR remained reassuring. Fifteen days after the delivery of the first fetus, regular uterine contractions started and followed by spontaneous membrane rupture. Magnesium sulfate infusion was repeated with the same loading and maintenance doses. The fetus would need the neonatal intensive care unit (NICU) due to GA. Hence, the patient had to be transferred to another hospital prior to the delivery due to lack of space at our NICU. The second fetus was delivered with cesarean section (CS) due to breech presentation at 28 weeks 2 days GA and weighed 1010 grams. One-minute and five-minute APGAR scores were 8 and 9 , respectively. The newborn was discharged in good condition on the postnatal 40th day. At 15 days of corrected age, her neurologic examination was unremarkable, and echocardiography revealed a secundum type atrial septal defect. At ten months of corrected age, neurologic examination and BAYLEY III scores were normal apart from mildly increased tonus in all extremities and brisk deep tendon reflexes. The child's cognitive outcomes through 6 years of age is normal, and she does not have any sequel. There were no abnormalities requiring intervention during the mother's follow-up.

\section{DISCUSSION}

We present a DID case which the first baby born in 26 weeks via vaginal birth and the second baby was delayed until 28 weeks 2 days. DID can be considered as an option when the delivery of one fetus of a MP is inevitable; however, the optimal management for DID is not well established due to lack of randomized control trials and report of unsuccessful cases. In our case after the first fetus delivered, we performed a cervical cerclage followed by tocolysis, antibiotic prophylaxis, and magnesium sulfate administration. We administered multiple times of betamethasone to induce fetal lung maturation. According to a randomized controlled study of repeated doses compared with single dose betamethasone including 502 pregnant women, rates of composite morbidity did not differ between the groups (2). However, based on the recent ACOG Committee Opinion single dose of betamethasone is recommended (3). We administered magnesium sulfate more than once because of the high possibility of preterm labor due to PPROM. The University of Adeline guideline had published before our case which suggested magnesium sulfate administration to prevent cerebral palsy (4).
Neurologic and psychomotor examinations of the baby were normal with only minimal increase in muscle tone. The latest ACOG Committee Opinion recommends magnesium sulfate administration for short period ( $<48$ hours) before the labor (5). Hence, it is wise to consider giving magnesium sulfate to protect the vulnerable brain in cases considering applying delayed delivery interval; however, it is still controversial. Magnesium sulfate administration should be performed in optimum conditions, and both patient and fetus should be closely monitored for the possible side effects. In our case the first baby was delivered via vaginal birth. In a Cochrane review it was concluded that limited evidence was available to choose CS over vaginal delivery for preterm births (6). However, If CS had been performed for our patient the second fetus would not be able to reach 28 weeks GA.

A systematic review including 128 cases aimed to assess the benefit of DID procedure for the remained fetus after the first fetus delivered (7). They reported significantly lower mortality risk for the second fetus (relative risk = $0.44,95 \%$ confidence interval $=0.34-0.57)(7)$. Also, mortality risk of second fetus was significantly lower if the first fetus was delivered at $\geq 24$ weeks GA (relative risk $=0.37,95 \%$ confidence interval $=0.17-0.82$ ) (7). A recent study has reported a good outcome with delayed interval delivery including nine twin and five triplet pregnancies (8). Mean GA at delivery was $21+6$ for the first fetus and $26+0$ for the second fetus (8). The mean interval of the delay was 29.3 days (2-82 days) and mortality rate was $53.3 \%$ for the first fetuses and $17.6 \%$ for the second fetus(es) (8).

DID can be an option for selected patients with multiple pregnancies complicated with presenting of first fetus due to preterm labor, cervical insufficiency or premature rupture of membranes. However, there is no consensus regarding the optimum approach of multiple pregnancies that might be the candidates for DID. Besides, this procedure can lead to some maternal complications including postpartum infection, hysterectomy, hemorrhage requiring transfusion, sepsis, and Clostridium difficile colitis with overall rate of $31.6 \%$ (9). The patients who underwent this procedure must be monitored closely. The risks and benefits should be discussed with the patient with an informed consent for the procedure in detail.

\section{CONCLUSION}

Delaying the birth of the remaining fetus(es) after the birth of the first one has a significant impact on their survival (10). However, this cannot be applied if the clinical findings of infection exist. Antibiotic therapy together with tocolysis should be administered immediately due to PPROM. Although cervical cerclage is still controversial, it can be performed in the patients who do not have uterine contractions, bleeding, or rupture of the membrane of the second fetus like in our case.

\section{Conflict of interest}

No conflict of interest was declared by the authors.

\section{REFERENCES}

1. Carson JL. Twins born with an interval of 44 days. Br Med J 1880;1:242.

2. Guinn DA1, Atkinson MW, Sullivan $L$, Lee $M$, MacGregor $S$, Parilla BV, Davies J, Hanlon-Lundberg K, Simpson L, Stone J, Wing D, Ogasawara K, Muraskas J. Single vs weekly courses of antenatal corticosteroids for women at risk of preterm delivery: A randomized controlled trial. JAMA. 2001;286:1581-7.

3. ACOG Committee Opinion No.713, Antenatal Corticosteroid Therapy for Fetal Maturation. August 2017

4. Australian Research Centre for Health of Women and Babies. Antenatal Magnesium Sulphate Prior to Preterm Birth for Neuroprotection of the Fetus, Infant and Child - National Clinical Practice Guidelines. Adelaide. ARCH; 2010

5. ACOG Committee Opinion No. 652, Magnesium Sulfate Use in Obstetrics, January 2016

6. Alfirevic Z, Milan SJ, Livio S. Caesarean section versus vaginal delivery for preterm birth in singletons. Cochrane Database Syst Rev. 2012; 6: CD000078.

7. Feys $S$, Jacquemyn $Y$. Delayed-interval delivery can save the second twin evidence from a systematic review. Facts Views Vis Obgyn. 2016 ;8:223-31.

8. Kolben T, Fischer D, Ruehl I, Franz M, Hester A, Kolben TM, Deppe C, Delius $M$, Friese K, Mahner S, Hasbargen U, Hübener C. Delayed interval delivery in multiple gestations: the Munich experience. Arch Gynecol Obstet. 2018 Nov 1. doi: 10.1007/s00404-018-4959-2

9. Roman AS, Fishman S, Fox N, et al. Maternal and neonatal outcomes after delayed-interval delivery of multifetal pregnancies. Am J Perinatol 2011; 28:91.

10. Uludağ S, Gezer A, Koşcağız Cansever I, Duru Suiçmez B. Delayed interval delivary in multiple gestation. Cerrahpasa J Med 2007; 38: 62 - 4 